\title{
Variations in Diurnal Uptake of Water and Nutrients by Tomato Plants Grown Hydroponically
}

\author{
Satoshi Terabayashi, Ken Takii and Takakazu Namiki \\ Faculty of Agriculture, Kyoto Prefectural University, Sakyo-ku, Kyoto 606
}

\begin{abstract}
Summary
Water and nutrient uptake by tomato (Lycopersicon esculentum MILL cv. Ohgata-Fukuju) plants during the day (7:00 to 19:00) and night (19:00 to 7:00) was estimated for 4 consecutive days during 4 seasons of the year. Percentage of uptake rate during the night to that of the 24-hr day is expressed as URN. URNs of phosphate ions ranging from 40 to $50 \%$ were always the highest among the nutrients examined. URN of water tended to be high during the cool seasons. Changes in URN of nutrients, except for $\mathrm{Ca}$, did not always correspond to the URN of water.

The balance between the cations and anions absorbed was calculated. More cations than anions were absorbed during the day but the situation was reversed at night. Electrical imbalance of either cations or anions was negligible when calculated for the entire day.

These observations indicate that phosphate ions and other nutrients are taken up actively against the concentration gradient (culture solution) at night and that URNs of nutrients are influenced little by the rate of water uptake. Diurnal variations in phosphate ions uptake are small.
\end{abstract}

\section{Introduction}

Absorption rate of water and nutrients by plant roots is influenced by environmental conditions, such as air and root temperatures $(7,10,16)$, air humidity $(3,5)$, light intensity $(6,19)$, etc. Insofar as these factors fluctuate diurnally, rates of water and nutrient uptake during the night should differ from those which occur in the day.

A considerable number of articles exsists on water and nutrient uptake under given environmental conditions. Also, considerable attention has been paid to the change in absorption at different growth stages of crops $(12,20)$. Little work, however, has been done on diurnal change in absorption $(1,2)$, or the relationship between day- and night-time absorption by crops grown in water culture.

The purpose of the present study was to describe the aspects of uptake of water and nutrients during the day and night by tomato plants grown in water culture.

Received for publication 22 January 1990.

\section{Materials and Methods}

\section{Experiment 1}

Seeds of tomato cv. Ohgata-Fukuju were sown in nursery soil on November, 1982, February, May, and August, 1983. At the first leaf stage, seedlings were transplanted into water culture bed filled with a half strength Enshishoho culture solution (9) consisting of $4 \mathrm{meq} / \mathrm{liter} \mathrm{KNO}_{3}, 4 \mathrm{meq} /$ liter $\mathrm{Ca}\left(\mathrm{NO}_{3}\right)_{2}, \quad 2 \mathrm{meq} / \mathrm{liter} \quad \mathrm{MgSO}_{4}, \quad 2 \mathrm{meq} /$ liter $\mathrm{NH}_{4} \mathrm{H}_{2} \mathrm{PO}_{4}, 3 \mathrm{ppm} \mathrm{Fe}$ added as Fe-EDTA and full strength microelements of Enshishoho (Mn $0.5 \mathrm{ppm}, \mathrm{B} 0.5 \mathrm{ppm}, \mathrm{Zn} 0.05 \mathrm{ppm}, \mathrm{Cu} 0.02 \mathrm{ppm}$, Mo $0.01 \mathrm{ppm})$. The concentrations of nitrate- and ammonium-nitrogen were $8 \mathrm{meq} / \mathrm{liter}$ and $2 / 3$ meq/liter, respectively; the total $\mathrm{N}$ was $121.5 \mathrm{ppm}$.

At the first flower truss bloom stage, 5 plants were transplanted into each of two plastic containers (25 liter) containing about 20 liters of solution which was aerated continuously. The experiment was started a few days later. Water and nutrient uptake during the day (7:00 to 19:00) and night (19:00 to 7:00) was measured separately for 4 
days. Plants were transferred from $\mathrm{N}$-container prepared for measurement of uptake during the night to D-container prepared for measurement of uptake during the day at 7:00, and returned from the D-container to $\mathrm{N}$-container at 19:00. Each uptake was determined by measuring the decrease in solution volume and nutrient contents at the start and the end of the experiment. Water uptake by plants was determined from decrease of solution minus water evaporation from the surface of solution in a container without plants. The rate of uptake was expressed on the basis of dry weight of the whole plant or per plant. Solution was not renewed and $\mathrm{pH}$ of solution was not controlled during the measurement.

Measurements were made in February, April, July and October. Air temperature was controlled, to maintain the minimum of $14^{\circ} \mathrm{C}$. Maximum and minimum temperatures were recorded. Potassium, calcium and magnesium concentrations were determined with an atomic absorption spectro photometer, nitrate concentration with a nitrate electrode and phosphate concentration with a colorimetric photometer.

We use the two terms, URN and N/W. URN is the percentage of uptake rate during the night to that of the 24-hr day, and N/W is the ratio of the nutrient absorbed in plant to a liter of water absorbed from culture solution by the plant during the day and night.

\section{Experiment 2}

Seeds of tomato cv. Ohgata-Fukuju were sown in nursery soil on 20 September 1983. Seedlings at the first leaf stage were transplanted to hydroponic bed filled with a half strength Enshishoho culture solution. When the plants reached the 13-leaf stage, 4 were transplanted into each of two 4 -liter plastic containers filled with culture solution and transferred to a growth cabinet. The cabinet was maintained at $25^{\circ} \mathrm{C}$, and under a 12 -hr photoperiod having a light intensity of $10 \mathrm{Klx}$. The uptake of nutrient and water was measured during the light (12-hr) and dark (12-hr) periods separately for 6 consecutive days. Plants were transferred from the $\mathrm{D}$-container to $\mathrm{N}$-container at the start of the light and dark period as in Exp. 1. The nutrient solution in these containers were renewed every 2 days.

\section{Results}

\section{Experiment 1}

Comparisons between rates of water and nutrient uptake and the percentage of rate of uptake rate at night to those of the 24-hr day (URN) revealed that seasonal fluctuations in water uptake were larger during the day than at night (Fig. 1). For example, in Oct. water uptake rates during the day and night were 2.3 and 1.3 times greater, respectively, than rates found in April.

URN ranged from 12 to $19 \%$ for water throughout the 4 seasons, but it varied from 41 to $50 \%$ for phosphate and from 30 to $41 \%$ for other nutrients.
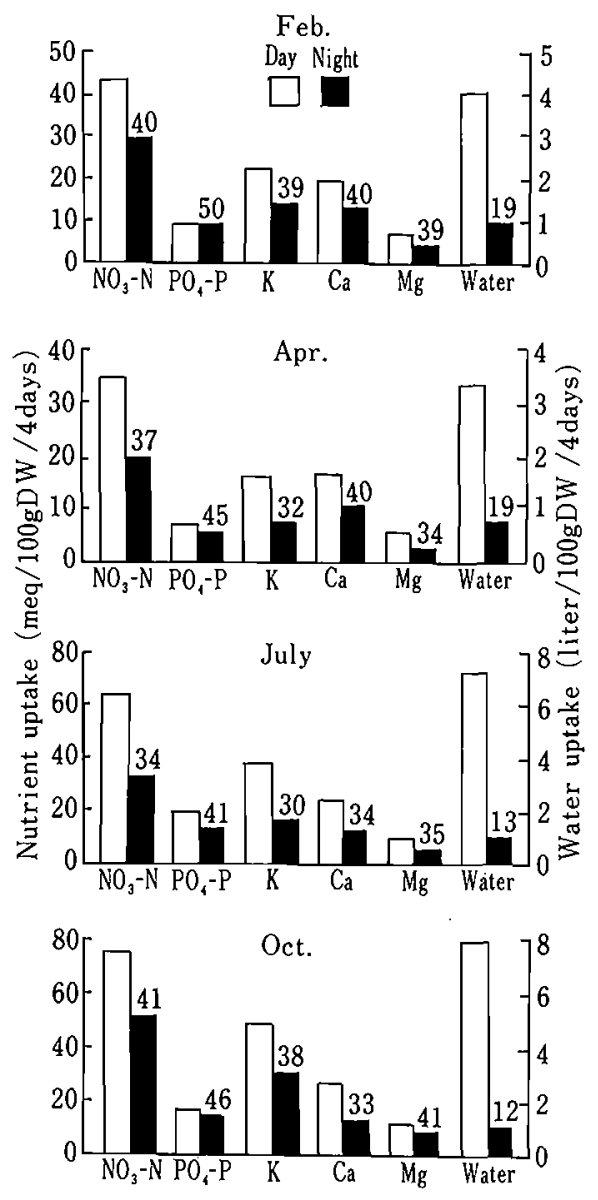

Fig. 1. Water and nutrient uptake by tomato plants during the day (7:00 to 19:00) and the night (19:00 to 7:00) measured in 4 seasons. Figures on top of right columns are percentages of uptake rate during the night to that of a whole day. 
Among 5 macro-elements, URN of phosphate was consistently the highest.

$(\mathrm{N} / \mathrm{W}) /$ concentration of the element in the culture solution which is the ratio between the rate of nutrient to water absorbed and the concentration of the nutrient in culture solution revealed that the ratio during the night was always higher than that during the day (Fig. 2). This tendency was most evident in phosphate uptake. The ratio during the day for each element was similar, approximating unity. The N/W ratio was almost the same as the concentration of the nutrient in solution. N/W during the night for each element differed in 4 seasons. N/W of nitrate, phosphate and potassium during the night were higher than those for calcium or magnesium, except for calcium in April.

Comparison between rates of individual nutrient and nitrate uptake showed that uptake of phosphate was relatively larger during the night than during the day but that of potassium was reversed being smaller at night than during the day (Table 1). Relative uptake of magnesium/nitrate during the day and night was constant during the entire experimental period. There was no constancy between absorbed calcium to nitrate during the day and night for 4 experiments.

The balance of cations $(\mathrm{K}+\mathrm{Ca}+\mathrm{Mg})$ and of anions $\left(\mathrm{NO}_{3}-\mathrm{N}+\mathrm{PO}_{4}-\mathrm{P}\right)$ absorbed, expressed in milliequivalents, is shown in Table 2 . In this table, phosphate ion is regarded as univalent (4). During the day, the balance favored the cations, whereas at night it favored the anions. However, the ionic balance for the whole day was near neutral.

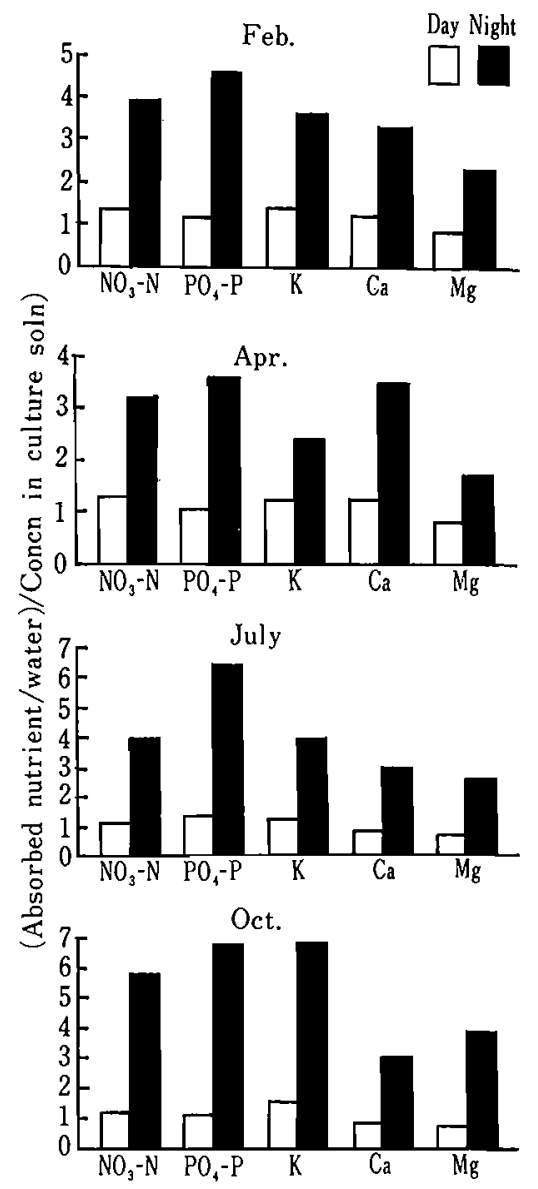

Fig. 2. Rate of nutrient to water absorbed by tomato plants as compared to concentration of the element in culture solution.

Table 1. Nutrient uptake rates (meq/100g DW/ 4 days) by tomato plants based on nitrate- $\mathrm{N}$ being 100 .

\begin{tabular}{|c|c|c|c|c|c|c|}
\hline \multirow{2}{*}{ Month } & \multirow{2}{*}{$\begin{array}{l}\text { Time of } \\
\text { absorption }\end{array}$} & \multicolumn{5}{|c|}{ Nutrients uptake } \\
\hline & & $\mathrm{NO}_{3}-\mathrm{N}$ & $\mathrm{PO}_{4} \cdot \mathrm{P}$ & $\mathrm{K}$ & $\mathrm{Ca}$ & $\mathrm{Mg}$ \\
\hline \multirow[t]{2}{*}{ Feb. } & day & 100 & 21 & 52 & 44 & 16 \\
\hline & night & 100 & 31 & 48 & 44 & 15 \\
\hline \multirow[t]{2}{*}{ Apr. } & day & 100 & 20 & 47 & 48 & 15 \\
\hline & night & 100 & 28 & 38 & 55 & 14 \\
\hline \multirow[t]{2}{*}{ July } & day & 100 & 30 & 59 & 38 & 16 \\
\hline & night & 100 & 40 & 49 & 38 & 17 \\
\hline \multirow[t]{2}{*}{ Oct. } & day & 100 & 23 & 65 & 36 & 16 \\
\hline & night & 100 & 29 & 59 & 26 & 17 \\
\hline
\end{tabular}




\section{Experiment 2}

Water and nutrient uptake and URN data (Fig. 3) revealed that URN of water was higher than that in Exp. 1. The difference is attributed to the inhibition of transpiration on account of the high humidity and low light intensity in the growth chamber. The URN values of nutrient, however, were similar to those obtained in the greenhouse. URN of phosphate was $44 \%$, the highest among the elements measured.

\section{Discussion}

URN of water and nutrient was generally low in July when the air temperatures attained the maximum and minimum of $37^{\circ}$ and $23^{\circ} \mathrm{C}$ and the days were long. URN were high in February when the maximum and minimum temperatures were only $26^{\circ}$ and $14^{\circ} \mathrm{C}$, respectively, and the days were short. The higher URN in a cool season may have been caused by reduction in water uptake and/or reduction in nutrient uptake itself during the day (Fig. 1). This reduction may be mainly influenced by lower temperature during the day and shorter day length in cool season than in hot season.

Values of URN of nutrients except for calcium did not always correspond to the changes in URN

Table 2. The balance between milliequivalents of cations and anions absorbed.

\begin{tabular}{|c|c|c|}
\hline Month & $\begin{array}{l}\text { Time of } \\
\text { absorption }\end{array}$ & $\begin{array}{c}\text { The balance between milliequivalents } \\
\text { of cations and anions abosrbed }\end{array}$ \\
\hline \multirow{3}{*}{ Feb. } & day & +2.1 \\
\hline & night & -0.9 \\
\hline & Whole day & +1.2 \\
\hline \multirow{3}{*}{ Apr. } & day & +1.2 \\
\hline & night & -0.8 \\
\hline & whole day & +0.4 \\
\hline \multirow{3}{*}{ July } & day & +1.8 \\
\hline & night & -3.2 \\
\hline & whole day & -1.4 \\
\hline \multirow{3}{*}{ Oct. } & day & +7.3 \\
\hline & night & -4.3 \\
\hline & whole day & +3.0 \\
\hline
\end{tabular}

Cations: Potassium, calcium and magnesium. Anions: Nitrate and phosphate.

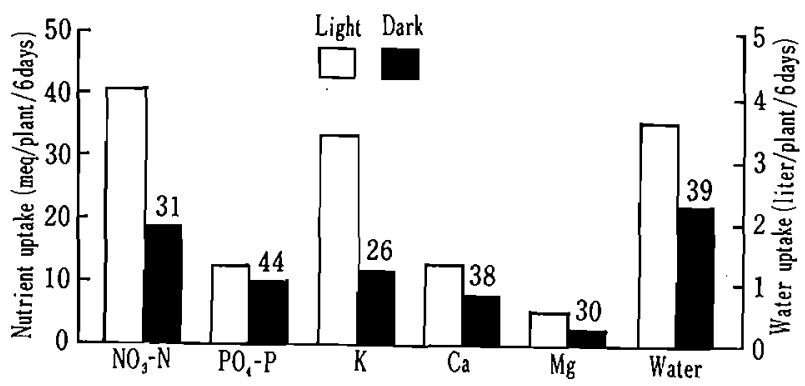

Fig. 3. Water and nutrient uptake by tomato plants during the light (12 hr) and the dark $(12 \mathrm{hr})$ periods. Figures on top of right columns are percentage of uptake rate during the dark period to that of a whole day. 
of water. Calcium and magnesium uptakes were thought to be a function of changes in water uptake. A high correlation between URN of calcium and of water was found in the 4 seasons. This tendency was also found in Exp. 2 conducted in the growth cabinet. URN of calcium was almost equal to that of water, but, magnesium uptake was influenced more by nitrate uptake rather than that by water. Hence, the magnesium/nitrate ratio was constant both during the day and night in 4 seasons of measurement.

URN of phosphate was always the highest among the macroelements in all the seasons of measurement. It was $50 \%$ in February, whereas that of water was $19 \%$ (Fig. 1). A strong diurnal variation in water uptake was observed, but it was not noticed in phosphate uptake.

These data suggest that phosphate is absorbed strongly during the night. Masuda (13) reported that phosphate was absorbed at a high rate during the night, and that phosphate concentration of xylem sap was much higher in night-time than in day-time for tomato and cucumber. URN of phosphate calculated from figures obtained by Hanson et al. (8) on bean was about $40 \%$. Characteristic vigorous phosphate uptake during the night was found not only in tomato but also in other crops. The reason for the vigorous uptake of phosphate during the night is yet not clear.

Phosphate uptake was inhibited by low root zone temperature (14). Wilcok (21) observed that phosphate uptake was suppressed at soil temperature below $13^{\circ} \mathrm{C}$. Adams (1) reported a high correlation between phosphate uptake and solution temperature with cucumber grown in recirculating solution culture. In the present experiment conducted in 4 seasons, the minimum air temperature, though not always equal to the root temperature was maintained above $13^{\circ} \mathrm{C}$, a critical temperature, for phosphate uptake. The differences between the maximum and the minimum temperatures in 4 seasons were from $12^{\circ}$ to $15^{\circ} \mathrm{C}$. The difference in phosphate uptake during the day and night was very small in spite of large diurnal fluctuations in temperature. Therefore, our data do not support the thesis that phosphate uptake depends on diurnal changes in air and root temperatures.

We found that phosphate uptake during the night by phosphate-starved plants cultured in phosphate-free culture solution for a few weeks in- creased faster than that of day time uptake after a resupply of phosphate (17). When we compared the compensative uptake of phosphate by tomato plants cultured in phosphate-free culture solution between the day and night, compensative phosphate uptake was found to be larger at night than during the day (18). Although similar results were obtained with other elements, this tendency was especially noticeable for phosphate. Phosphate uptake strongly depends on physiological status of the plant, presumably the demand for phosphate at least during the night. Williams (22) reported that the rate of phosphate uptake was susceptible to the internal factors such as demand for phosphate rather than the external factors such as phosphate supply.

On the other hand, it is conceivable that phosphate concentration in culture solution was high enough to covercome the effect of temperature. Nielsen and Cunningham (15) concluded that soil temperature had little effect on the uptake of phosphate from soil rich in this element. Kato et al. (11) reported that the concentration of phosphate in culture solution was one or two order higher than that of soil solution.

The results of our experiments disclose that diurnal variations of air temperature and light intensity had a little effect on phosphate uptake during the day and night for tomatoes grown in solution culture, particularily when the roots are supplied with $1 / 2$ strength Enshishoho solution containing 2 meq/liter of phosphate.

Yamasaki et al. (23) described the relationship of cations and anions absorbed by tomato, cucumber, lettuce, etc. The relationships of absorbed ions expressed in milliequivalents were as follows: $\mathrm{NO}_{3}-\mathrm{N}=\mathrm{K}+\mathrm{Ca} ; \mathrm{PO}_{4}-\mathrm{P}=\mathrm{Mg}$; and $\mathrm{NO}_{3}-\mathrm{N}: \mathrm{PO}_{4}-\mathrm{P}=$ $3 \sim 4: 1$. Except for the relationship between phosphate- $\mathrm{P}$ and $\mathrm{Mg}$ (Table 1), our data on diurnal uptake obtained in this study are in agreement with those relations reported by Yamasaki et al. (23)

\section{Literature Cited}

1. Adams, P. 1980. Nutrient uptake by cucumbers from recirculating solution. Acta Hort. $98: 119-126$.

2. Adams, P. and D.M. Masaey. 1980. Nutrient uptake by tomatoes from recirculating solutions. ISOSC Proc. p. 71-80. 
3. Armstrong, M. and E. Kirkby. 1979. The influence of humidity on the mineral composition of tomato plants with special reference to Ca distribution. Plant Soil. $52: 427-435$.

4. Bieleski, R.L. and I.B. Ferguson. 1983. Physiology and metabolism of phosphate and its compounds. p. 422-445. In : Encyclopedia of plant physiology. New Series 15A. Springer, Berlin, Heidelberg, New York, Tokyo.

5. Bradfield, E.G. and C.G. Guttridge. 1984. Effects of night-time humidity and nutrient solution concentration on the calcium content of tomato fruit. Scientia Hortic. $22: 207-217$.

6. Chu, C.B. and E.W. Toop. 1975 . Effects of substrate potassium, substrate temperature and light intensity on growth and uptake of major cations by greenhouse tomato plants. Can. J. Plant. Sci. $55: 121-126$.

7. Cooper, A. J. 1973. Root temperature and plant growth. Commonwealth Agr. Bureaux, England.

8. Hanson, J.B. and O. Biddulph. 1953. The diurnal variation in the translocation of mineral across bean roots. Plant Physiol. 28 : 356-370.

9. Hori, Y. 1966. Gravel-culture of vegetables and ornamental crops. p. 67-72. Yokendo, Tokyo. (In Japanese).

10. Hori, Y., K. Arai, T. Hosoya and M. Oyamada. 1968. Studies on the effects of root temperature and its combination with air temperature on growth and nutrition of vegetable crops. I. Cucumber, tomato, turnip and bean. Bull. Hort. Res. Sta. A7 : 187-214. (In Japanese).

11. Kato, H., N. Oka and T. Motoshima, 1985. Phosphorus accumulation in onion field soils. J. Soil Sci. Plant Nutrition. 56:279-284. (In Japanese).

12. Kondo, T. 1967. Absorption of nutrients and water by several kinds of vegetables in different stages of growth. Bull. Hort. Res. Sta. B7 : 57-71. (In Japanese).

13. Masuda, M. 1989. Mineral composition in xylem exudation of tomato and cucumber plants at midday and midnight. J. Japan. Soc. Hort. Sci. 58:619-625. (In Japanese).

14. Nielsen, K.F. 1974. Roots and root temperatures. p. 293-333. In : E.W. Carson (ed). The plant root and its environment. Univ. Press, Virginia.

15. Nielsen, K.F. and R.K. Cunningham. 1964. The effects of soil temperature, form and level of $\mathrm{N}$ on growth and chemical compostion of Italian ryegrass. Soil Sci. Soc. Amer. Proc. 28 : 213-218.

16. Papadopoulos, A.P. and H. Tiessen. 1987. Root and air temperature effects on the elemental composition of tomato. J. Amer. Soc. Hort. Sci. 112 : 988-993.

17. Terabayashi, S., K. Takii and T. Namiki. 1984. Relation between the percentage of uptake rate during the night to that of the $24-\mathrm{hr}$ day and the rate of nutrient to water absorbed as compared to the concentration of the nutrient of culture solution. Abstr. Japan. Soc. Hort. Sci. Autumn Meet : 244-245. (In Japanese).

18. Terabayashi, S., I. Muramatsu, T. Inada and T. Namiki. 1989. Growth of, and nutrient uptake by tomato plants cultured in phosphate free nutrient solution during day or night. Sci. Rep. Kyoto Pref. Univ., Agr. $41: 9-15$.

19. Tremblay, N., M. J. Trudel and A. Gosselin. 1984. Influence of supplementary lighting (HPS) on yield and mineral nutrition of tomato plants grown in hydroponic culture. ISOSC. Proc. p. 697-703.

20. Van Goor, B.J., A. de Jagar and W. Voogt. 1988. Nutrient uptake by some horticultural crops during the growing period. ISOSC. Proc. p. 163-176.

21. Wilcok, G.E., G.G. Martin and R. Langston. 1962. Root zone temperature and phosphorus treatment effects on tomato seedling growth in soil and nutrient solutions. Proc. Amer. Soc. Hort. Sci. $80: 522-529$.

22. Williams, R.F. 1948. The effects of phosphorus supply on the rate of intake of phosphorus and nitrogen and upon certain aspects of phosphorus metabolism in gramineous plants. Aust. J. SciRes. $1: 333-361$.

23. Yamasaki, K., Y. Suzuki and Y. Shinohara. 1976. Studies on the water culture of several vegetables with special reference to the control of nutrient solution and ratio of nutrient absorption per water consumption $(=\mathrm{n} / \mathrm{W})$. Memo. Fac. Agri. Tokyo Univ. Edu. 22 :53-100. (In Japanese). 
水耕栽培したトマトの昼間およU゙夜間の養水分吸収

\author{
寺林 敏・滝井 謙・並木隆和 \\ 京都府立大学脤学部 606 京都市左京区下鴨半木町
}

\begin{abstract}
摘要
トマト（品種：大型福寿）を水耕栽培し，昼間（7夜間吸収率にもっとも左右されやすかった。荃水分の 時から 19 時) と夜間 (19 時から翌朝 7 時) 各々の封間夜間吸収率は低温期に高い值を示方傾向が認められた.

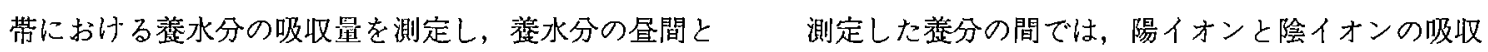
夜間の吸収の違いを比較, 検討した。

栽培時期の違いにかかわらず，1日の全吸収量に対 する夜間の吸収量の割合(夜間吸収率) は硝酸侦等素, リン，カリウム，カルシウム，マグネシウムの中で, 常にリンがいちばん高く，40５0\%の值を示した．五 つの僐分の中では，カルシウムの夜間吸収率が水分の 量の関係は，相対的に，昼間では陽イオンが，夜間で は除イオンが多く吸収されていた。

これらの結果から，リンは夜間においても槛極的に 吸収され，1日のうちでの吸収量の変動が極めて少な く，1日のうちでの光強度や気温の変化ならびに吸水 量の変化にも影㗽を受けにくいことが示された。
\end{abstract}

